\title{
Prenatal Stress Induces Schizophrenia-Like Alterations of Serotonin 2A and Metabotropic Glutamate 2 Receptors in the Adult Offspring: Role of Maternal Immune System
}

\author{
Terrell Holloway, ${ }^{1}$ José L. Moreno, ${ }^{1}$ Adrienne Umali, ${ }^{1}$ Vinayak Rayannavar, ${ }^{1}$ Georgia E. Hodes, ${ }^{3}$ Scott J. Russo, ${ }^{3,4}$ \\ and Javier González-Maeso ${ }^{1,2,4}$ \\ Departments of ${ }^{1}$ Psychiatry, ${ }^{2}$ Neurology, and ${ }^{3}$ Neuroscience and ${ }^{4}$ Friedman Brain Institute, Mount Sinai School of Medicine, New York, New York 10029
}

It has been suggested that severe adverse life events during pregnancy increase the risk of schizophrenia in the offspring. The serotonin $5-\mathrm{HT}_{2 \mathrm{~A}}$ and the metabotropic glutamate 2 (mGlu2) receptors both have been the target of considerable attention regarding schizophrenia and antipsychotic drug development. We tested the effects of maternal variable stress during pregnancy on expression and behavioral function of these two receptors in mice. Prenatal stress increased 5- $\mathrm{HT}_{2 \mathrm{~A}}$ and decreased mGlu2 expression in frontal cortex, a brain region involved in perception, cognition, and mood. This pattern of expression of $5-\mathrm{HT}_{2 \mathrm{~A}}$ and $\mathrm{mGlu} 2$ receptors was consistent with behavioral alterations, including increased head-twitch response to the hallucinogenic 5- $\mathrm{HT}_{2 \mathrm{~A}}$ agonist DOI [1-(2,5-dimethoxy-4-iodophenyl)-2aminopropane] and decreased mGlu2-dependent antipsychotic-like effect of the mGlu2/3 agonist LY379268 (1R,4R,5S,6R-2-oxa-4aminobicyclo[3.1.0] hexane-4,6-dicarboxylate) in adult, but not prepubertal, mice born to stressed mothers during pregnancy. Cross-fostering studies determined that these alterations were not attributable to effects of prenatal stress on maternal care. Additionally, a similar pattern of biochemical and behavioral changes were observed in mice born to mothers injected with polyinosinic:polycytidylic acid [poly(I:C)] during pregnancy as a model of prenatal immune activation. These data strengthen pathophysiological hypotheses that propose an early neurodevelopmental origin for schizophrenia and other psychiatric disorders.

\section{Introduction}

There is extensive evidence to suggest that genetics plays a significant role in the etiology of schizophrenia (International Schizophrenia Consortium et al., 2008; Stefansson et al., 2008, 2009; Walsh et al., 2008; Purcell et al., 2009). However, the genetic determinants are complex, as has been suggested from studies on twins. Monozygotic twins have a concordance for schizophrenia of nearly 50\% (Cardno and Gottesman, 2000; Gottesman and Erlenmeyer-Kimling, 2001). Such results favor a significant contribution of genetic factors to the etiology of schizophrenia. At the same time, they argue for a significant role of environmental events in the development of this complex disease. Epidemiological studies have indicated that adverse life events that occurred during pregnancy, such as war (van Os and Selten, 1998; Malaspina et al., 2008), famine (Susser et al., 2008), and death or illness in a first-degree relative (Khashan et al., 2008), increase the risk of schizophrenia in the adult offspring. Similarly, maternal

Received May 14, 2012; revised 0ct. 3, 2012; accepted 0ct. 31, 2012.

Author contributions: T.H., G.E.H., S.J.R., and J.G.-M. designed research; T.H., J.L.M., A.U., and V.R. performed research; J.G.-M. analyzed data; J.G.-M. wrote the paper.

This work was supported by National Institutes of Health Grant R01 MH084894 (J.G.-M.) and R01 MH090264 (S.J.R.), Dainippon Sumitomo Pharma (J.G.-M.), National Alliance for Research on Schizophrenia and Depression (J.G.-M.), and the Mortimer D. Sackler Foundation (J.G.-M.).

The authors declare no competing financial interests.

Correspondence should be addressed to Dr. Javier González-Maeso, Department of Psychiatry, Mount Sinai School of Medicine, 1425 Madison Avenue, Box 1229, New York, NY 10029. E-mail: Javier.Maeso@mssm.edu.

DOI:10.1523/JNEUROSCI.2331-12.2013

Copyright $\odot 2013$ the authors $\quad 0270-6474 / 13 / 331088-11 \$ 15.00 / 0$ infections with a wide variety of agents (virus, bacteria, and protozoa) have been associated with an elevated risk of schizophrenia (e.g., influenza virus, rubella virus, bronchopneumonia, Toxoplasma gondii) (Menninger, 1919; Brown et al., 2001; Brown et al., 2004a; Brown et al., 2005). Several lines of evidence in rodent models and humans suggest that alterations in the maternal immune response during pregnancy are involved in the mechanisms underlying the link between prenatal adverse life events and schizophrenia (Brown et al., 2004b; Ashdown et al., 2006; Smith et al., 2007; Meyer et al., 2009a). However, the biochemical alterations responsible for the neuropsychiatric symptoms induced by maternal immune activation during pregnancy are as yet not fully understood.

Serotonin (5-HT) and glutamate systems are suspected in the pathophysiology of schizophrenia, as well as in the mechanism of action of antipsychotic drugs (Lieberman et al., 2008; GonzálezMaeso and Sealfon, 2009; Moreno et al., 2009; Ibrahim and Tamminga, 2011). Earlier studies have implicated 5HT2A (Htr2a), 5 HT2C (Htr2c), $m$ Glu2 (Grm2), and $m$ Glu3 (Grm3) genes in psychosis and antipsychotic responses (Egan et al., 2004; Quednow et al., 2008; Abdolmaleky et al., 2011; Matrisciano et al., 2011; Kurita et al., 2012; Lett et al., 2012; Liu et al., 2012). Frontal cortex, which plays a significant role in cognition and perception, has been implicated more recently in schizophrenia and other psychotic disorders (González-Maeso et al., 2007; GonzálezMaeso et al., 2008; González-Maeso and Sealfon, 2009). We have reported recently that, in postmortem prefrontal cortex of untreated schizophrenic subjects, the $5-\mathrm{HT}_{2 \mathrm{~A}}$ receptor is upregu- 
Table 1. Prenatal stress paradigm

\begin{tabular}{llc}
\hline Embryonic age & Day & Night \\
\hline E9.5 & Restraint $(30 \mathrm{~min})$ & \\
E10.5 & Cold exposure $(2 \mathrm{~h})$ & \\
E11.5 & Restraint $(30$ min $)$ & Light on \\
E12.5 & Electric footshock $(1 \mathrm{~h})$ & \\
E13.5 & Tail suspension $(30 \mathrm{~min})$ & Fast \\
E14.5 & Electric footshock $(1 \mathrm{~h})$ & \\
E15.5 & Forced swim $(30 \mathrm{~min})$ & \\
\hline
\end{tabular}

lated and the metabotropic glutamate 2 (mGlu2) receptor is downregulated, a pattern of expression that could predispose to psychosis (González-Maeso et al., 2008). A similar pattern of alteration in $5-\mathrm{HT}_{2 \mathrm{~A}}$ receptor and $\mathrm{mGlu} 2$ receptor densities was found in frontal cortex of adult mice born to influenza virusinfected mothers during pregnancy (Moreno et al., 2011). An extensive series of work has shown in rodent models that maternal stress during pregnancy elicits schizophrenia-like neurochemical and behavioral changes in the offspring. These alterations include changes in neurotransmitter receptor binding, long-lasting proinflammatory consequences, reprogramming of the hypothalamic-pituitary-adrenal (HPA) axis, rearrangement of chromatin structure, learning deficits, and behavioral disturbances in rodent models of psychosis, among others (Steptoe et al., 2001; Welberg and Seckl, 2001; Koenig et al., 2002; Seo et al., 2006; Van den Hove et al., 2006; VanbesienMailliot et al., 2007; Murgatroyd et al., 2009; Franklin et al., 2010; Morgan and Bale, 2011; Matrisciano et al., 2012).

Here, we studied the effects of maternal variable stress during pregnancy on the expression of $5-\mathrm{HT}_{2 \mathrm{~A}}$ and mGlu2 receptors in mouse frontal cortex. We next examined the behavioral effects of prenatal exposure to variable stress using mouse models of psychosis and antipsychotic-like response. Previous findings demonstrate that adverse life experiences profoundly modulate immune and inflammatory cell function (Vanbesien-Mailliot et al., 2007; García-Bueno et al., 2008). Our data suggest a potential role for the maternal immune system in the biochemical and behavioral alterations observed in mouse schizophrenia models of prenatal stress.

\section{Materials and Methods}

Animals. Timed-pregnant CD1 mice were obtained from Charles River Laboratories. Animals were shipped on day 7 of pregnancy. Animals were single housed at $12 \mathrm{~h} \mathrm{light/dark} \mathrm{cycle} \mathrm{at} 23^{\circ} \mathrm{C}$ in a humidity-controlled room with food and water ad libitum. The Institutional Animal Use and Care Committee at Mount Sinai School of Medicine approved all experimental procedures.

Prenatal stress paradigm. On day 9.5 of pregnancy, mice were randomly assigned to either control or variable stress conditions ( $n=24$ per group in two independent experiments). Pregnant dams assigned to the stress group were exposed to different stressors each day for $7 \mathrm{~d}$. Animals were subjected to stressors at different times each day to minimize predictability. Stressors included the following: (1) $30 \mathrm{~min}$ of restraint (day 9.5); (2) 120 min of cold exposure (day 10.5); (3) 30 min of restraint (day 11.5); (4) $60 \mathrm{~min}$ of electric footshock and lights on overnight (day 12.5); (5) 30 min of tail suspension (day 13.5); (6) 60 min of electric footshock and food and water deprivation overnight (day 14.5); and (7) $30 \mathrm{~min}$ of forced swim (day 15.5) (Table 1). Restraint was performed by placing the animal in a clear acrylic tube (internal diameter, $37 \mathrm{~mm}$; length, 55-124 $\mathrm{mm}$ ) with ample ventilation holes. Mice were able to move forward and backward within the tube but were unable to turn around. Mice were observed continuously and remained awake during the entire restraint procedure. Cold exposure was performed in a temperature-controlled room at $4^{\circ} \mathrm{C}$. For footshock, mice were placed inside of fear conditioning boxes (MED Associates) and received 100 random shocks of $0.45 \mathrm{~mA}$ (3 $\mathrm{s}$ each) over a period of $1 \mathrm{~h}$. For tail suspension, mice were fixed to a bar and left to hang in an inverted position. For the forced swim, mice were placed in a plastic cylinder filled with water kept at $23-26^{\circ} \mathrm{C}$. After each stress, animals were returned to their home cage. After birth, pups were left undisturbed with their mothers (except for animals who were crossfostered; see below). Offspring were separated from their mothers after 3 weeks, and males and females were caged separately in groups of three to five. Subsequent experiments were performed in adult (10-15 weeks) male mice or prepubertal mice (21-28 d). Animals from at least eight separate litters were subjected to the different protocols. Recent findings suggest that the increased incidence of schizophrenia is associated with maternal stress that occurred during the first 3 months of pregnancy (Khashan et al., 2008; Malaspina et al., 2008). We chose days 9.5-15.5 of pregnancy for variable stress because it is approximately midpregnancy in mouse, and this equates to the end of the first trimester of human pregnancy (Clancy et al., 2007).

Prenatal polyinosinic:polycytidylic acid treatment. On day 9.5 of pregnancy, mice received intraperitoneal injection of polyinosinic:polycytidylic acid [poly(I:C); 5 mg/kg; Sigma-Aldrich] or saline. Offspring were separated from their mothers after 3 weeks, and males and females were caged separately in groups of three to five. Subsequent experiments were performed in adult (10-15 weeks) male mice, unless otherwise indicated. Animals from at least six separate litters were subjected to the different protocols.

Postnatal cross-fostering. On the day of birth, offspring born to stressed and control dams were removed from the original mother and then placed with a surrogate rearing mother. Four experimental conditions were established: (1) pups originating from control mothers and fostered by surrogate control mothers; (2) pups originating from stressed mothers and fostered by surrogate control mothers; (3) pups originating from control mothers and fostered by surrogate stressed mothers; and (4) pups originating from stressed mothers and fostered by surrogate stressed mothers. Animals from at least eight separate litters were subjected to the different protocols.

Drug administration. DOI [1-(2,5-dimethoxy-4-iodophenyl)-2aminopropane] and MK801 [(5R,10S)-(+)-5-methyl-10,11-dihydro-5 $H$ dibenzo[a,d]cyclohepten-5,10-imine hydrogen maleate (dizocilpine)] were purchased from Sigma-Aldrich. LY379268 [(1R,4R,5S,6R)-4-amino-2oxabicyclo[3.1.0] hexane-4,6-dicarboxylic acid] was obtained from Tocris Bioscience. DOI and LY379268 were dissolved in saline. MK801 was dissolved in a minimal amount of DMSO and made up to volume with saline. The injected doses (intraperitoneally) were MK801 at $0.05,0.1$, and 0.5 $\mathrm{mg} / \mathrm{kg}, \mathrm{LY} 379268$ at $3.0,5.0$, and $8.0 \mathrm{mg} / \mathrm{kg}$, and DOI at $0.5,1.0,2.0$ $\mathrm{mg} / \mathrm{kg}$ unless otherwise indicated.

Mouse brain samples. The day of the experiment, mice were killed by cervical dislocation, and bilateral frontal cortex was dissected and frozen at $-80^{\circ} \mathrm{C}$ or immediately processed for RNA extraction and/or radioligand binding assays. Mice used in behavioral assays were not subsequently used for biochemical assays.

Radioligand binding. Experiments were performed as reported previously (González-Maeso et al., 2008). Briefly, [ $\left.{ }^{3} \mathrm{H}\right]$ ketanserin binding (10 $\mathrm{nM}$ ) was measured at equilibrium in $500 \mu$ laliquots ( $50 \mathrm{~mm}$ Tris- $\mathrm{HCl}, \mathrm{pH}$ 7.4) of membrane preparations that were incubated at $37^{\circ} \mathrm{C}$ for $60 \mathrm{~min}$. Nonspecific binding was determined in the presence of $10 \mu \mathrm{M}$ methysergide (Tocris Bioscience). $\left[{ }^{3} \mathrm{H}\right] \mathrm{LY} 341495$ binding (30 nM) was measured at equilibrium in $500 \mu \mathrm{l}$ aliquots (potassium phosphate buffer supplemented with $100 \mathrm{~mm}$ potassium bromide, $\mathrm{pH}$ 7.6) of membrane preparations that were incubated at $4^{\circ} \mathrm{C}$ for $60 \mathrm{~min}$. Nonspecific binding was determined in the presence of $1 \mathrm{~mm}$ L-glutamic acid (Tocris Bioscience). The concentration of radioligands was chosen based on previous findings in mouse schizophrenia models of maternal influenza virus infection (Moreno et al., 2011) and postmortem human brain of schizophrenic subjects (González-Maeso et al., 2008).

Quantitative real-time PCR. Quantitative real-time PCR (qRT-PCR) assays were performed in quadruplicate as described previously with minor modifications. Four genes were used as internal controls for normalization ( $\beta$-actin, gapdh, ribosomal protein s3, and mapkapk-5). For primer pair sequences, see González-Maeso et al. (2008). 
Head-twitch behavior. Head-twitch behavior was performed as reported previously (González-Maeso et al., 2007). Briefly, animals were injected with DOI or vehicle, and, 15 min later, they were placed into the center of a Plexiglas cage for $30 \mathrm{~min}$, during which they were videotaped at close range by a video camcorder positioned directly above the cage. Videotapes were scored for head twitches by an experienced observer blind to maternal adverse life event and drug treatment.

Locomotor activity. Motor function (locomotor activity) was assessed using a computerized three-dimensional activity monitoring system (AccuScan Instruments) as reported previously with minor modifications (Moreno et al., 2011). Briefly, the activity monitor has 32 infrared sensor pairs with 16 along each side spaced $2.5 \mathrm{~cm}$ apart. The system determines motor activity based on frequency of interruptions to infrared beams traversing the $x, y$, and $z$ planes. For basal locomotor activity, mice were placed in the locomotor chamber under normal lighting conditions and allowed to habituate for $5 \mathrm{~min}$. After habituation, the locomotor activity was measured for $60 \mathrm{~min}$. For modulation of locomotor activity, mice were left to habituate in the locomotor box for $90 \mathrm{~min}$ before injection of the tested drug(s) and monitored for $2 \mathrm{~h}$ after injection. Horizontal activity and vertical activity were automatically determined from the interruptions of beams in the horizontal and vertical planes, respectively.

Discrete trials rewarded delayed spatial alternation. Working memory was tested using a T-maze alternation task. The experiments were performed in a T-maze constructed of wood and painted black. The walls were $15 \mathrm{~cm}$ high, and the alleys were $10.5 \mathrm{~cm}$ wide. The length of the main alley was $28 \mathrm{~cm}$, and the length of the side alleys was $22.5 \mathrm{~cm}$. The side alleys were closed off from the main alley by movable doors. A week before habituation, all animals were partially food restricted (each animal received $2 \mathrm{~g}$ of food per day) and remained that way throughout the remaining part of the experiment. This maintained each animal above $85 \%$ of its free-feeding body weight. A video camera was situated $\sim 1 \mathrm{~m}$ above the T-maze to videotape the test session. The T-maze was cleaned between different animals but not between different trials. The food reward was a $14 \mathrm{mg}$ salt pellet (Bio-Serv F05684). The full experiment consisted of three parts: habituation, training, and testing. During habituation, all animals were placed on the T-maze until they ate two pieces of food or $90 \mathrm{~s}$ had elapsed. This was repeated three times a day for $5 \mathrm{~d}$. During training, all animals received six trials a day per day. Each trial consisted of two runs: a forced run and a free run. On the forced run, mice were forced to obtain a piece of food from one goal arm of the T-maze, with the other goal arm blocked by its door. Animals were then placed back into the start arm for $10 \mathrm{~s}$ delay period. At the beginning of the free run, the mice were allowed to choose either goal arm. If the mice chose the arm opposite to the one they had been forced into during the forced run, they received the food reward. If the mice chose the same arm into which they had been forced, they received no food reward. There was a 5 min intertrial interval. The training period ended after control animals made $>70 \%$ correct choices on 2 consecutive days. Animals took $7-12 \mathrm{~d}$ to reach the criterion. Animals that did not reach the criterion by $14 \mathrm{~d}$ were rejected from the study. In this study, $5 \%$ of mice belonged to this latter group. Mice were then tested for their performance at 10 or $40 \mathrm{~s}$ delay periods. Mice were given three $10 \mathrm{~s}$ delay and three $40 \mathrm{~s}$ delay trials during the day of testing. For drug testing, mice were given six $10 \mathrm{~s}$ delay trials $15 \mathrm{~min}$ after drug exposure. The sequence of delays and forced-run food locations (left or right) were randomized each day, with the stipulation that the same delay or the same forced-arm location could not be used for three trials in a row. Goal entries were defined as placing four paws in the arm.

Statistical analyses. Statistical significance of experiments involving two groups was assessed by Student's $t$ test. Statistical significance of experiments involving two or more groups and two or more treatments was assessed by two-way ANOVA, followed by Bonferroni's post hoc test. The level of significance was chosen at $p=0.05$. All data are presented as mean \pm SEM.

\section{Results}

To evaluate the extent to which maternal stress during pregnancy alters biochemical and behavioral phenotypes related to schizo-
A

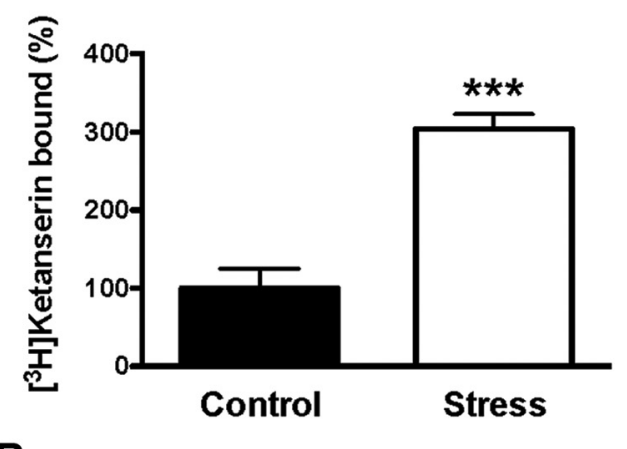

B

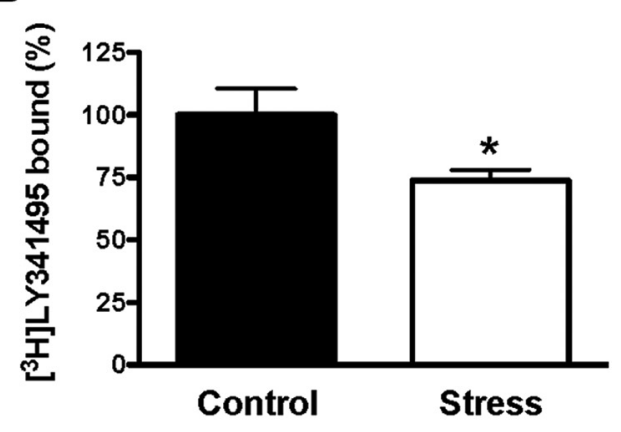

C

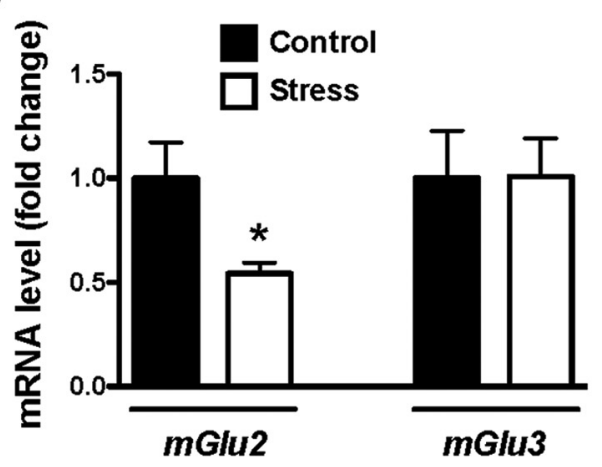

Figure 1. Maternal variable stress during pregnancy affects the expression of $5-\mathrm{HT}_{2 \mathrm{~A}}$ and mGlu2 receptors in the adult offspring. $A$, Density of $5-\mathrm{HT}_{2 \mathrm{~A}}$ receptor shown as $\left[{ }^{3} \mathrm{H}\right]$ ketanserin binding in mouse frontal cortex $(n=11-12)$. $\boldsymbol{B}$, Density of mGlu2/3 receptor shown as $\left[{ }^{3} \mathrm{H}\right] \mathrm{LY} 341495$ binding in mouse frontal cortex $(n=9)$. Data are shown as percentage of specific binding in frontal cortex of adult mice born to stressed mothers relative to controls. $\boldsymbol{C}$, Expression of $m$ Glu2 and $m$ Glu3 mRNA in frontal cortex determined by qRT-PCR ( $n=11-12$ ). ${ }^{*} p<0.05,{ }^{* * *} p<0.001$, Student's $t$ test. All data are presented as mean \pm SEM.

phrenia in the offspring, we established a model of variable and unpredictable stress in mice. Pregnant females were exposed to different stressors from E9.5 to E15.5. No decrease in litter size or the appearance or capacity of the mice to thrive was noted in mice born to stressed mothers relative to controls: stressed mothers gave birth to $11.33 \pm 0.71$, whereas control mice gave birth to $9.16 \pm 0.47$. The litter size was reduced in mice born to mothers exposed to more severe stressful situations (data not shown).

The $5-\mathrm{HT}_{2 \mathrm{~A}}$ receptor and the $\mathrm{mGlu} 2$ receptor in brain frontal cortex have been reported to be involved in psychotic-like symptoms and antipsychotic drug action (González-Maeso et al., 2008; Fribourg et al., 2011; Kurita et al., 2012). We first investigated the density of binding sites for $5-\mathrm{HT}_{2 \mathrm{~A}}$ and $\mathrm{mGlu} 2 / 3$ receptors in frontal cortex of adult mice born to stressed mothers during pregnancy. The receptor densities in frontal cortex membrane preparations from adult mice born to stressed mothers were 
A

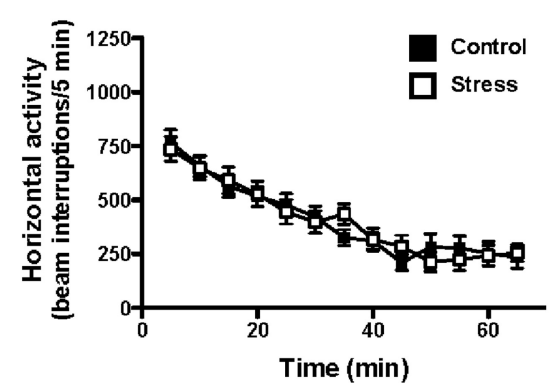

C

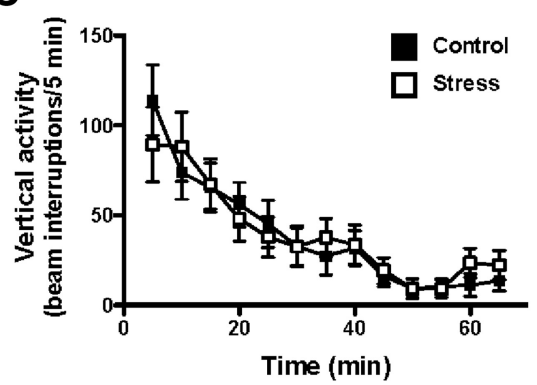

B

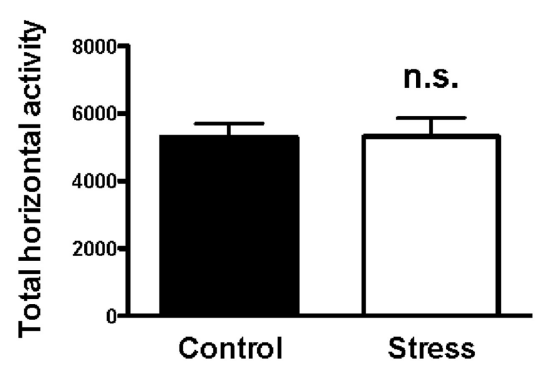

D

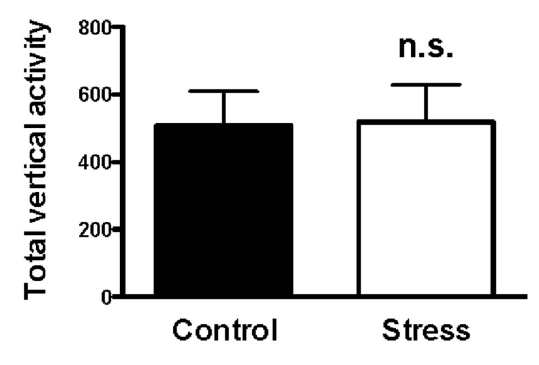

Figure 2. Exploratory activity in the open-field test. Horizontal activity $(\boldsymbol{A}, \boldsymbol{B})$ and vertical activity $(\boldsymbol{C}, \boldsymbol{D})$ in adult mice born to stressed mothers and controls. Both time course $(\boldsymbol{A}, \boldsymbol{C})$ and total counts $(\boldsymbol{B}, \boldsymbol{D})$ of the effects of maternal stress are shown $(n=$ $32-42)$. n.S., Not significant, Student's $t$ test. All data are presented as mean \pm SEM.

significantly altered, showing increased $\left[{ }^{3} \mathrm{H}\right]$ ketanserin binding to the $5-\mathrm{HT}_{2 \mathrm{~A}}$ receptor (Fig. $1 A$ ) and decreased $\left[{ }^{3} \mathrm{H}\right] \mathrm{LY} 341495$ binding to the mGlu2/3 receptors (Fig. $1 B$ ). The radioligand $\left[{ }^{3} \mathrm{H}\right]$ LY341495 binds with high affinity to both mGlu2 and mGlu3 receptors (Schweitzer et al., 2000). mRNA assays showed that expression of $m G l u 2$, but not $m G l u 3$, was decreased in frontal cortex of adult mice born to stressed mothers during pregnancy (Fig. 1C).

Spontaneous locomotor activity in the open field is generally considered as one of the variables reflecting exploratory behavior (Nestler and Hyman, 2010). Two-way repeated-measures ANOVA indicated absence of effect of maternal variable stress on horizontal $\left(F_{(1,70)}=0.01 ; p>0.05\right)$ or vertical $\left(F_{(1,40)}=0.01 ; p>\right.$ 0.05 ) activity in the adult offspring (Fig. $2 A, C$ ). Similarly, analysis of the total horizontal and vertical activity for the entire $60 \mathrm{~min}$ indicated that neither horizontal distance nor rearing was significantly affected by maternal stress (Fig. $2 B, D$ ).

The clinical effects of hallucinogenic drugs, such as psilocybin, DOI, and lysergic acid diethylamide, closely resemble a set of positive symptoms in schizophrenia (Vollenweider et al., 1998; González-Maeso and Sealfon, 2009). We have shown previously that the head-twitch behavior is reliably and robustly elicited by hallucinogenic $5-\mathrm{HT}_{2 \mathrm{~A}}$ receptor agonists and is absent in $5-\mathrm{HT}_{2 \mathrm{~A}}$ knock-out mice (González-Maeso et al., 2007). Modulation of locomotor hyperactivity induced by MK801 and other noncompetitive NMDA receptor antagonists has also been used as mouse models of psychosis and antipsychotic drug action (Bradford et al., 2010). Previous findings, including ours, demonstrate that activation of mGlu2, and not mGlu3, by the mGlu2/3 agonist LY379268 reduces the locomotor hyperactivity induced by MK801 (Woolley et al., 2008; Fribourg et al., 2011). To question whether maternal stress during pregnancy causes behavioral alterations that resemble symptoms of schizophrenia in the offspring, we investigated the behavioral responses induced by the psychedelic drugs DOI and MK801 in adult mice born to stressed mothers.
As expected (Canal et al., 2010), DOI induced head-twitch response in a dosedependent manner (Fig. 3A). Two-way ANOVA indicated a statistical significance for the effects of the treatment $\left(F_{(3,46)}=292.42 ; p<0.001\right)$ and maternal stress $\left(F_{(1,46)}=30.81 ; p<0.001\right)$. Significance was also found for the interaction between treatment and maternal stress $\left(F_{(3,46)}=4.43 ; p<0.01\right)$. Notably, post hoc analysis showed that the head-twitch response induced by the hallucinogenic $5-\mathrm{HT}_{2 \mathrm{~A}}$ receptor agonist DOI was significantly increased in adult mice born to stressed mothers during pregnancy (Fig. $3 A$ ), (DOI at $0.5 \mathrm{mg} / \mathrm{kg}, p<0.001$; DOI at $1.0 \mathrm{mg} / \mathrm{kg}, p<0.001 ; \mathrm{DOI}$ at $2.0 \mathrm{mg} / \mathrm{kg}$, $p>0.05)$.

We next examined the effect of treatment with the mGlu2/3 receptor agonist LY379268 on the MK801-dependent locomotor response in the adult offspring of mice born to stressed mothers during pregnancy and controls. As expected (Moreno et al., 2011), our pilot studies indicated that MK801 (0.5 mg/kg) induces a robust increase in locomotor activity (Fig. $3 B-D$ ) compared with vehicle, an effect that was not observed in response to lower doses of MK801 (0.05 and $0.1 \mathrm{mg} / \mathrm{kg}$; data not shown). We therefore selected the optimal dose of MK801 as $0.5 \mathrm{mg} / \mathrm{kg}$ to induce a significant hyperlocomotor activity. Mice were administered LY379268 (or vehicle), followed by MK801 (or vehicle). Twoway ANOVA indicated a statistical significance for the effects of LY379268 treatment $\left(F_{(3,80)}=15.79 ; p<0.001\right)$ and maternal stress $\left(F_{(1,80)}=10.74 ; p<0.01\right)$. Significance was not found for the interaction between treatment and maternal stress $\left(F_{(3,80)}=\right.$ $1.06 ; p>0.05)$. The post hoc analysis showed that the hyperlocomotor activity induced by MK801 $(0.5 \mathrm{mg} / \mathrm{kg})$ was not affected by maternal stress $(p>0.05)$. Interestingly, post hoc analysis also showed that the effect of LY379268 on the MK801-induced hyperlocomotor activity was reduced in adult mice born to stressed mothers compared with controls (Fig. 3B-D) (LY379268 at 3.0 $\mathrm{mg} / \mathrm{kg}, p>0.05 ; \mathrm{LY} 379268$ at $5.0 \mathrm{mg} / \mathrm{kg}, p<0.05 ; \mathrm{LY} 379268$ at $8.0 \mathrm{mg} / \mathrm{kg}, p<0.05)$.

Because there have been studies suggesting that maternal perturbations do not stop at birth with the cessation of the stress paradigm (Darnaudéry et al., 2004; Vanbesien-Mailliot et al., 2007), we performed cross-fostering experiments to determine the effects of maternal behavior after delivery in the adult offspring. Compared with prenatally unstressed mice that were raised by stressed surrogate mothers, the head-twitch response to the hallucinogenic $5-\mathrm{HT}_{2 \mathrm{~A}}$ receptor agonist DOI $(0.5 \mathrm{mg} / \mathrm{kg})$ was significantly increased in prenatally stressed mice that were raised by unstressed surrogate mothers (Fig. 4A). Thus, two-way ANOVA indicated a statistical significance for the effects of the treatment $\left(F_{(1,40)}=1355.18 ; p<0.001\right)$ and maternal stress $\left(F_{(3,40)}=13.44 ; p<0.001\right)$. Significance was also found for the interaction between treatment and maternal stress $\left(F_{(3,40)}=\right.$ 13.44; $p<0.001)$. Notably, post hoc analysis showed that the head-twitch response induced by the hallucinogenic $5-\mathrm{HT}_{2 \mathrm{~A}}$ receptor agonist DOI was significantly increased in prenatally stressed mice that were raised by unstressed surrogate mothers 
A

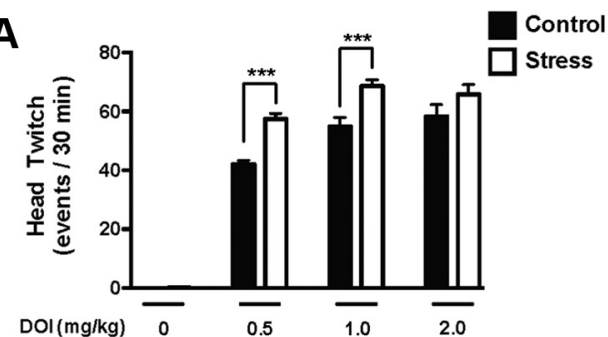

B

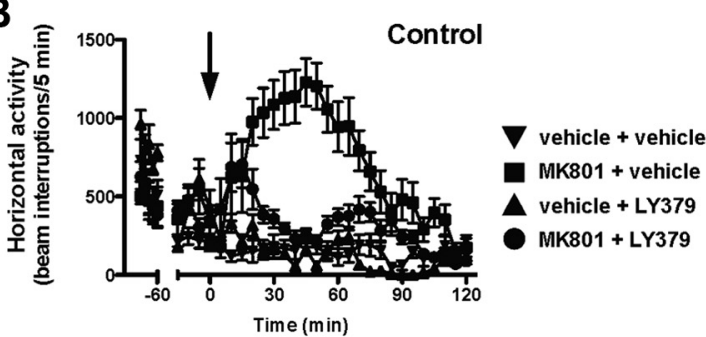

C

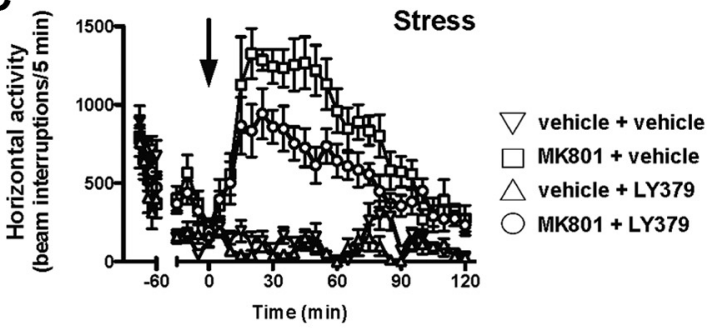

D

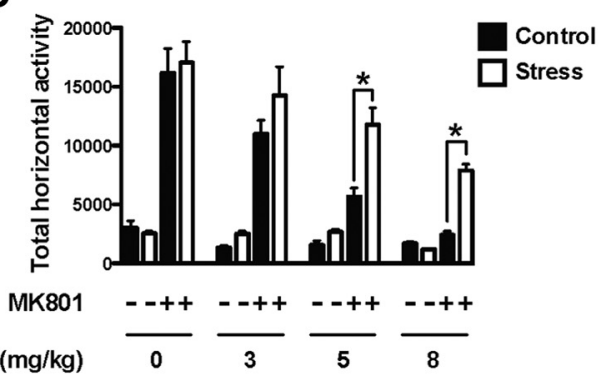

Figure 3. $\quad A$, Head-twitch behavioral response is increased in adult mice born to stressed mothers during pregnancy. Mice were injected with DOI $(0.5,1.0$, or $2.0 \mathrm{mg} / \mathrm{kg})$, or vehicle $(n=$ $6-10) .{ }^{* *} p<0.001$, Bonferroni's post hoc test of two-way ANOVA. $\boldsymbol{B}-\boldsymbol{D}$, Decreased effect of LY379268 on the MK801-stimulated locomotor activity in the offspring of stressed mothers during pregnancy ( $\boldsymbol{C}, \boldsymbol{D}$, white) compared with controls ( $\boldsymbol{B}, \boldsymbol{D}$, black). The panels depict the time course of MK801-induced locomotion in 5 min blocks ( $\boldsymbol{B}, \boldsymbol{C})$. Mice were administered LY379268 $(5 \mathrm{mg} / \mathrm{kg})$ or vehicle, followed by MK801 or vehicle. Time of injections is indicated by arrows. $D$, Data summary of the total MK801-induced locomotor response as a summation of horizontal activity from $t=20$ to $t=120$. Mice were administered $L Y 379268(3.0,5.0$, or $8.0 \mathrm{mg} / \mathrm{kg})$ or vehicle, followed by MK 801 or vehicle ( $n=9-18$ per group). ${ }^{*} p<0.05$, Bonferroni's post hoc test of two-way ANOVA. All data are presented as mean \pm SEM.

$(p<0.001)$ compared with prenatally unstressed mice that were raised by unstressed surrogate mothers. Head-twitch response was also increased in prenatally stressed mice that were raised by stressed surrogate mothers $(p<0.001)$. This increase in headtwitch response was not observed in prenatally unstressed mice that were raised by stressed surrogate mothers $(p>0.05)$.

We next studied the effect of LY379268 on the MK801 hyperlocomotor activity after cross-fostering of litters. The locomotor response to MK801 was not affected in either mice prenatally exposed to maternal stress and adopted by control mothers or mice prenatally unstressed and adopted by stressed mothers (Fig. $4 B$ ) compared with mice prenatally unstressed and adopted by

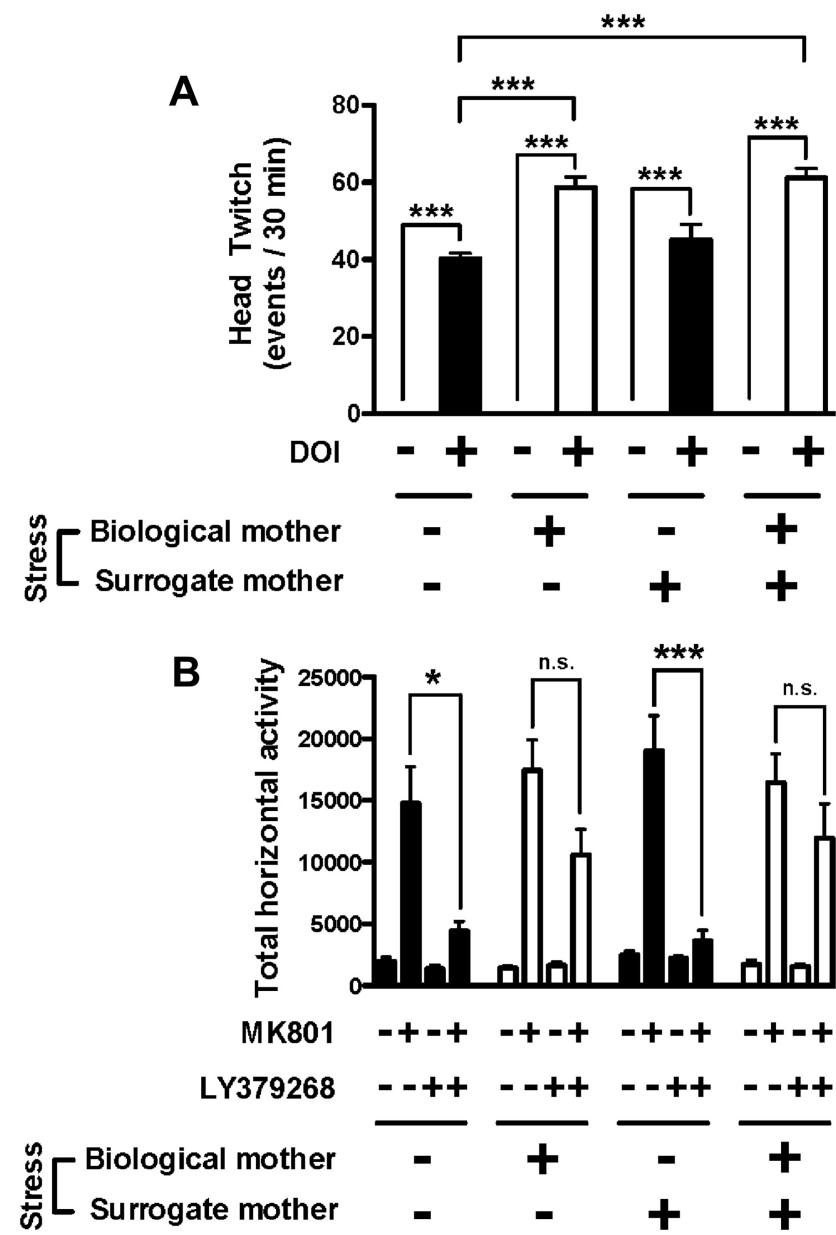

Figure 4. $\quad \boldsymbol{A}$, Head-twitch behavioral response in mice prenatally unstressed and raised by control mothers, in mice prenatally exposed to maternal stress and raised by control mothers, in mice prenatally unstressed and raised by stressed mothers, and in mice prenatally exposed to maternal stress raised and by stressed mothers. Mice were injected with D0I $(0.5 \mathrm{mg} / \mathrm{kg})$ or vehicle ( $n=6-8$ per group). ${ }^{* *} p<0.001$, Bonferroni's post hoc test of two-way ANOVA. $\boldsymbol{B}$, The MK801-stimulated locomotor activity is attenuated by LY379268 (5 mg/kg) in mice prenatally unstressed and raised by stressed mothers, but it is not affected in mice prenatally stressed and raised by control mothers. Summary of the total MK801-induced locomotor response as a summation of horizontal activity from $t=20$ to $t=120$. Mice were administered LY379268 or vehicle, followed by MK801 or vehicle ( $n=8-16$ per group). ${ }^{*} p<0.05,{ }^{* * *} p<0.001$, Bonferroni's post hoc test of two-way ANOVA; n.S., not significant. All data are presented as mean \pm SEM

unstressed mothers (Fig. 4B). Similar MK801-induced hyperlocomotor behavior was also observed in mice prenatally stressed and adopted by stressed mothers (Fig. 4B). Two-way ANOVA indicated a statistical significance for the effects of LY379268 (5 $\mathrm{mg} / \mathrm{kg})$ treatment $\left(F_{(1,78)}=39.94 ; p<0.001\right)$ and maternal stress $\left(F_{(3,78)}=3.42 ; p<0.05\right)$. Significance was also found for the interaction between treatment and maternal stress $\left(F_{(3,78)}=4.34\right.$; $p<0.01)$. Post hoc analysis showed that LY379268 reduced the locomotor response induced by MK801 in mice born to control mothers and raised by control surrogate mothers $(p<0.05)$ and in mice born to control mothers and raised by stressed surrogate mothers $(p<0.001)$. This effect of LY379268 was absent in mice born to stressed mothers and raised by control surrogate mothers $(p>0.05)$ and in mice born to stressed mothers and raised by stressed surrogate mothers $(p>0.05)$.

In humans, the onset of schizophrenia typically occurs during late adolescence of early adulthood. We examined the effect of 
A
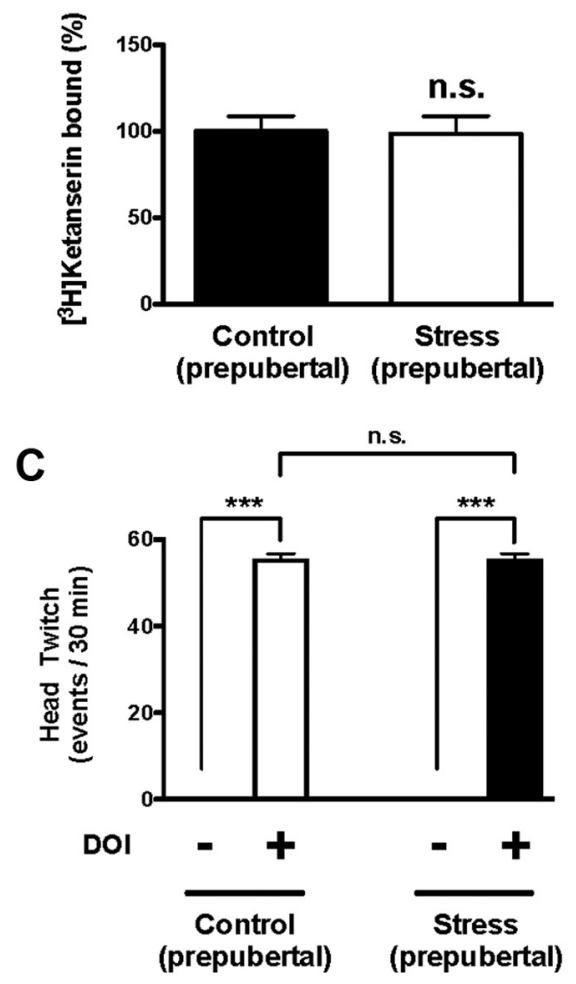

B

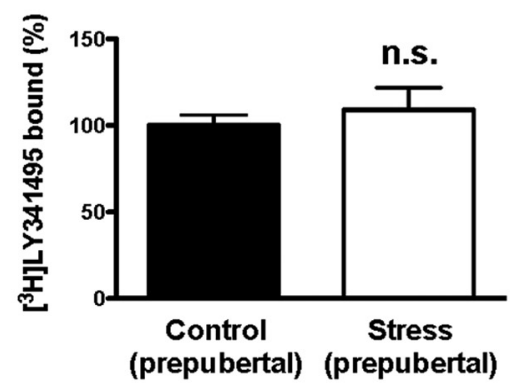

D

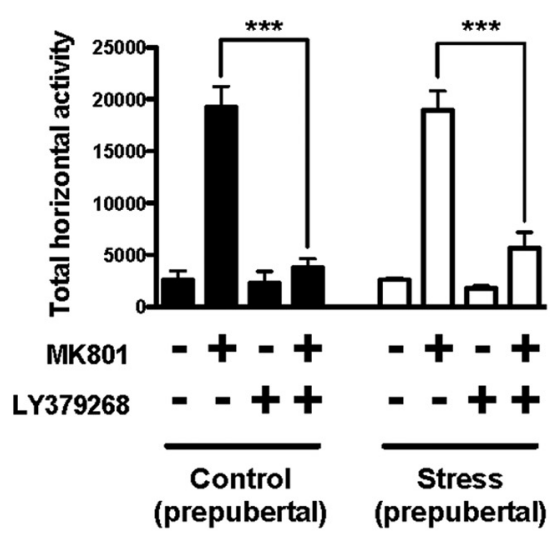

Figure 5. A, Density of $5-\mathrm{HT}_{2 \mathrm{~A}}$ receptor shown as $\left[{ }^{3} \mathrm{H}\right]$ ketanserin binding in frontal cortex of prepubertal (21-28 $\mathrm{d}$ old) mice $(n=9)$. $B$, Density of mGlu2/3 receptor density shown as $\left[{ }^{3} \mathrm{H}\right] \mathrm{LY} 341495$ binding in frontal cortex of prepubertal mice $(n=$ 16 -18). Data are shown as percentage of specific binding in frontal cortex of prepubertal mice born to stressed mothers relative to controls. $C$, Head-twitch behavioral response in prepubertal mice born to stressed mothers during pregnancy. Mice were injected with D0I $(0.5 \mathrm{mg} / \mathrm{kg})$ or vehicle $(n=6-8){ }^{* * *} p<0.001$, Bonferroni's post hoc test of two-way ANOVA; n.s., not significant. $\boldsymbol{D}$, The MK801-stimulated locomotor activity is attenuated by LY379268 $(5 \mathrm{mg} / \mathrm{kg})$ in control mice (black) and in prepubertal mice born to stressed mothers during pregnancy (white). Summary of the total MK801-induced locomotor response as a summation of horizontal activity from $t=20$ to $t=120$. Mice were administered LY379268 or vehicle, followed by MK801 or vehicle $(n=6-8$ per group). ${ }^{* *} p<0.001$, Bonferroni's post hoc test of two-way ANOVA. All data are presented as mean \pm SEM.

maternal variable stress during pregnancy in preadolescent offspring (21-28 d old). Neither $\left[{ }^{3} \mathrm{H}\right]$ ketanserin binding (Fig. $5 A$ ) nor $\left[{ }^{3} \mathrm{H}\right]$ LY341495 binding (Fig. $5 B$ ) was significantly affected in frontal cortex of young mice born to stressed mothers during pregnancy. The head-twitch behavior induced by DOI $(0.5 \mathrm{mg} /$ $\mathrm{kg}$ ) was not significantly altered by maternal variable stress during pregnancy in prepubertal animals (Fig. 5C). Thus, two-way ANOVA indicated a statistical significance for the effect of the treatment $\left(F_{(1,24)}=1682.62 ; p<0.001\right)$ but not for the effect of maternal stress $\left(F_{(1,24)}=0.00 ; p>0.05\right)$. Post hoc analysis showed that DOI induced head-twitch response in prepubertal mice born to stressed mothers $(p>0.001)$ and controls $(p>0.001)$. Post hoc analysis also showed that the head-twitch response induced by DOI was not affected in prepubertal mice born to stressed mothers compared with prepubertal mice born to control mothers $(p>0.05)$.

The locomotor response to MK801 was not affected in prepubertal mice born to stress mothers compared with prepubertal mice born to control mothers (Fig. 5D). Two-way ANOVA indicated that there was a significant effect of LY379268 (5 mg/kg) on the locomotor response induced by $\operatorname{MK801}\left(F_{(1,22)}=72.93 ; p<\right.$ $0.001)$ but not a significant effect of maternal stress $\left(F_{(1,22)}=\right.$ $0.22 ; p>0.05)$. Post hoc analysis showed that LY379268 reduced the locomotor response induced by MK801 in preadolescent mice born to stressed $(p<0.001)$ mothers and controls $(p<0.001)$.

Our results thus far indicate that maternal variable stress during pregnancy induces upregulation of the $5-\mathrm{HT}_{2 \mathrm{~A}}$ receptor and downregulation of the mGlu2 receptor in frontal cortex of the adult offspring. These biochemical finding are consistent with the schizophrenialike behavioral alterations observed in adult mice born to stressed mothers. In addition, it is known that severe life experiences modulate immune and inflammatory cell function (Vanbesien-Mailliot et al., 2007; García-Bueno et al., 2008). We reported previously that maternal influenza viral infection causes upregulation of the $5-\mathrm{HT}_{2 \mathrm{~A}}$ receptor and downregulation of the $\mathrm{mGlu} 2$ receptor in frontal cortex of the adult offspring (Moreno et al., 2011). Together, these findings led us to hypothesize that activation of the maternal immune system during pregnancy might be the mechanism underlying this dysregulation in expression and behavioral function $5-\mathrm{HT}_{2 \mathrm{~A}}$ and $\mathrm{mGlu} 2$ receptors in the adult offspring.

Injection of poly(I:C) into pregnant rodents, like other immune activating treatments, induces strong innate immune responses and produces schizophrenia-like abnormalities in the adult offspring (Cai et al., 2000; Meyer et al., 2006, 2008; Smith et al., 2007). We tested whether the poly(I:C) model of maternal immune activation alters expression and behavioral function of $5-\mathrm{HT}_{2 \mathrm{~A}}$ and $\mathrm{mGlu} 2$ receptors in the adult offspring. As shown above in our mouse model of maternal variable stress, no decrease in litter size or the appearance or capacity of the mice to thrive was noted in mice born to poly(I:C)-injected mothers relative to controls. Poly(I: C)-injected mothers gave birth to $10.01 \pm 1.15$, whereas control mice gave birth to $9.67 \pm 0.88$. Radioligand binding assays showed increased $\left[{ }^{3} \mathrm{H}\right]$ ketanserin binding (Fig. 6A) and decreased $\left[{ }^{3} \mathrm{H}\right] \mathrm{LY} 341495$ binding (Fig. 6B) in frontal cortex of mice born to poly(I:C)-injected mothers compared with mice born to controls. Head-twitch response induced by the hallucinogenic $5-\mathrm{HT}_{2 \mathrm{~A}}$ receptor agonist DOI was significantly increased in adult mice born to poly(I:C)-injected mothers compared with mice born controls (Fig. 6C). Thus, two-way ANOVA indicated a statistical significance for the effect of the treatment $\left(F_{(1,28)}=\right.$ 169.76; $p<0.001)$ and poly $(\mathrm{I}: \mathrm{C})\left(F_{(1,28)}=14.65 ; p>0.001\right)$. Significance was also found for the interaction between DOI treatment and poly(I:C) $\left(F_{(1,28)}=14.31 ; p<0.001\right)$. Post hoc analysis showed that DOI induced head-twitch response in prepubertal mice born to poly(I:C)-injected mothers $(p<0.001)$ and controls $(p<0.001)$. Post hoc analysis also showed that the head-twitch response induced by DOI was increased in adult mice born to poly(I:C)-injected mothers $(p<0.001)$.

Maternal immune activation during pregnancy did not affect the MK801-dependent locomotor response in the offspring (Fig. $6 D)$. Two-way ANOVA also indicated that there was a significant 
effect on the locomotor response induced by $\operatorname{MK} 801\left(F_{(1,25)}=16.31 ; p<0.001\right)$. Post hoc analysis showed that LY379268 reduced the locomotor response induced by MK801 in both mice born to control mothers $(p<0.01)$ and mice born to poly(I:C)-injected mothers $(p<0.05)$. Notably, post hoc analysis also showed that the effect of LY379268 on the MK801-dependent locomotor response was significantly reduced in adult mice born to poly(I:C)-injected mothers compared with adult mice born to mockinjected mothers $(p<0.05)$.

Spontaneous locomotor activity in the open field was not affected by maternal immune activation. Two-way repeatedmeasures ANOVA indicated absence of effect of maternal variable stress on horizontal $\left(F_{(1,21)}=0.12 ; p>0.05\right)$ or vertical $\left(F_{(1,21)}=0.06 ; p>0.05\right)$ activity in the adult offspring (Fig. $7 A, C$ ). Analysis of the total horizontal and vertical activity for the entire $60 \mathrm{~min}$ also indicated that neither horizontal distance nor rearing was significantly affected by maternal stress (Fig. $7 B, D$ ).

Schizophrenia patients demonstrate impairments on a variety of working memory tests (Elvevåg and Goldberg, 2000). In rodents, working memory can be reliably assessed in a T-maze using a discrete-trial delayed alternation task (Deacon and Rawlins, 2006). In a first series of experiments, control mice and mice born to mothers injected with poly(I:C) during pregnancy were trained and tested in parallel as described in Materials and Methods. Mice born to mothers injected with poly(I:C) during pregnancy and controls exhibited similar learning curves with near-chance level performance (40-50\% of correct arm entries) between days 1 and 4 of training (performed with $10 \mathrm{~s}$ intertrial delays; data not shown), followed by a gradual improvement that reached a plateau of $>70 \%$ correct arm entries between days 11 and 14 of the training (10 s delay; data not shown). Retention times in the holding box were then increased to 10 and $40 \mathrm{~s}$ delays. As can be seen in Figure $8 A$, the performance of mice born to control mothers remained stable at 10 and $40 \mathrm{~s}$. However, the performance of mice born to mothers injected with poly(I:C) was unchanged at $10 \mathrm{~s}$ but deteriorated significantly as the delay interval increased to $40 \mathrm{~s}$ (Fig. $8 A$ ). In a second series of experiments, we found that MK801 impaired choice accuracy in the T-maze delayed alternation task at 10 s delay, an effect that was reversed by LY379268 in mice born to control mothers (Fig. $8 B$ ). In contrast, the effect of LY379268 on MK801-induced impairment in the T-maze at $10 \mathrm{~s}$ delay was reduced in mice born to mothers injected with poly(I:C) during pregnancy (Fig. 8B).

\section{Discussion}

Our results provide evidence that unpredictable stress during pregnancy alters the expression of $5-\mathrm{HT}_{2 \mathrm{~A}}$ and $\mathrm{mGlu} 2$ receptors in mouse frontal cortex, leading to schizophrenia-like behavior in
B
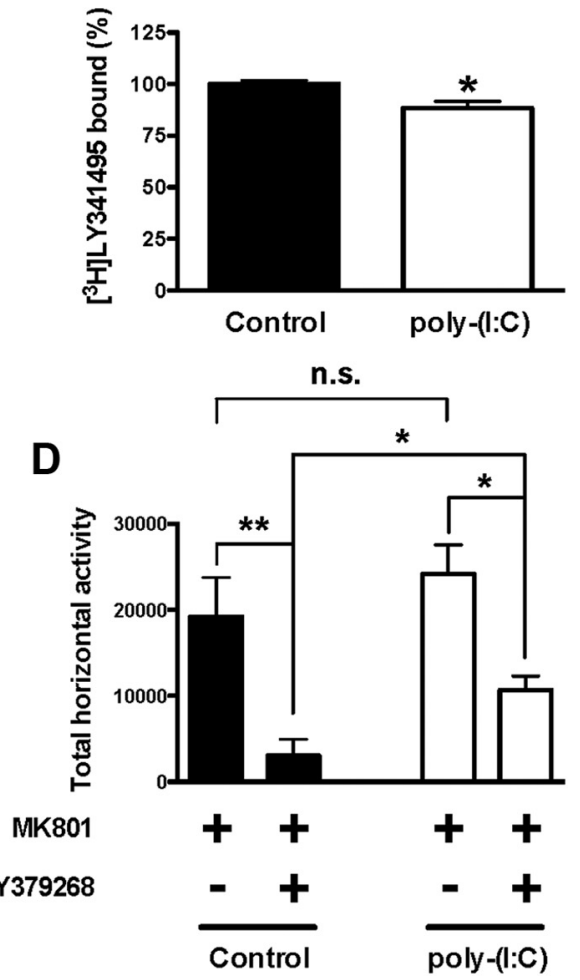

Figure 6. $\quad A$, Density of $5-\mathrm{HT}_{2 \mathrm{~A}}$ receptor shown as $\left[{ }^{3} \mathrm{H}\right] \mathrm{ketanserin} \mathrm{binding} \mathrm{in} \mathrm{frontal} \mathrm{cortex} \mathrm{of} \mathrm{adult} \mathrm{mice} \mathrm{born} \mathrm{to} \mathrm{mothers} \mathrm{injected} \mathrm{with} \mathrm{poly}(\mathrm{l}: \mathrm{C})$ with poly(l:C) during pregnancy. Mice were injected with DOl $(0.5 \mathrm{mg} / \mathrm{kg})$ or vehicle $(n=8){ }^{* * *} p<0.001$, Bonferroni's post hoc test of two-way ANOVA.D, The MK801-stimulated locomotor activity is attenuated by $L Y 379268(5 \mathrm{mg} / \mathrm{kg})$ in control mice (black) and in adultmice born to mothers of horizontalactivityfrom $t=20$ to $t=120$. Micewereadministered LY379268 orvehicle,followed byMK801 ( $n=6$ pergroup). ${ }^{*} p<0.05,{ }^{* *} p<$ 0.01, Bonferroni's posthoc test of two-way ANOVA; n.s., not significant. All data are presented as mean \pm SEM.

the adult offspring. Maternal infection and maternal stress are among the most prominent environmental risk factors for schizophrenia and other psychiatric disorders. Based on our previous findings with mouse models of maternal influenza viral infection (Moreno et al., 2011), we tested the hypothesis that maternal stress would induce long-lasting alterations in expression and behavioral function of $5-\mathrm{HT}_{2 \mathrm{~A}}$ and mGlu2 receptors in the adult offspring. Results revealed three key findings. First, maternal stress during pregnancy causes upregulation of the $5-\mathrm{HT}_{2 \mathrm{~A}}$ receptor and downregulation of the mGlu2 receptor in brain frontal cortex of the adult offspring. These alterations are consistent with those observed previously in brain frontal cortex of adult mice born to influenza-virus-infected mothers (Moreno et al., 2011). Second, the biochemical alterations correlate with behavioral deficiencies, showing increased head-twitch response induced by the hallucinogenic $5-\mathrm{HT}_{2 \mathrm{~A}}$ receptor agonist DOI and decreased antipsychotic-like effects of the mGlu2/3 agonist LY379268 on the MK801-dependent locomotor response in mice born to stressed mothers. The schizophrenia-like alterations were not observed in preadolescent mice and were not significantly affected by changes in maternal behavior after the mice were born. Third, abnormalities in expression and behavioral function of $5-\mathrm{HT}_{2 \mathrm{~A}}$ and mGlu2 receptors were also found in the adult offspring of dams exposed during pregnancy to poly(I:C). To- 


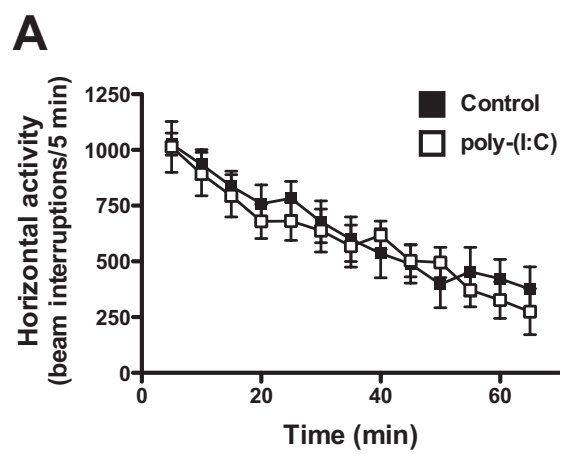

\section{B}

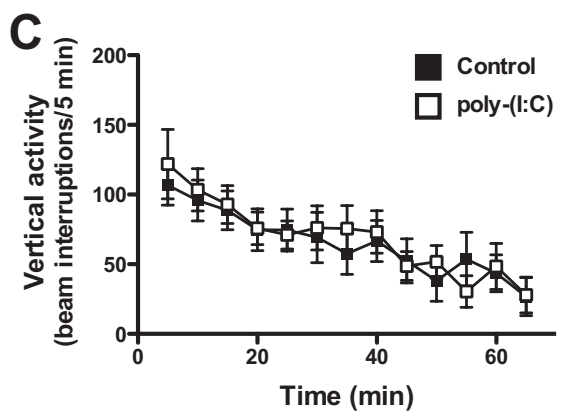

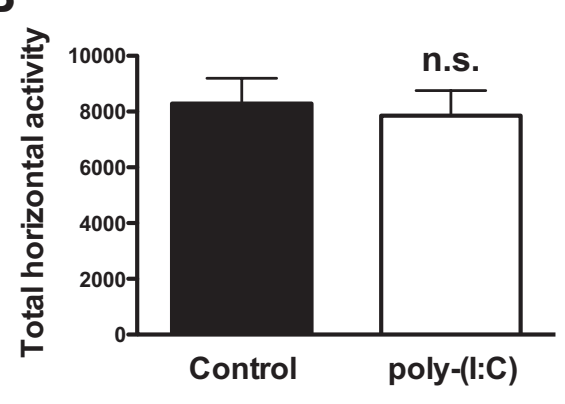

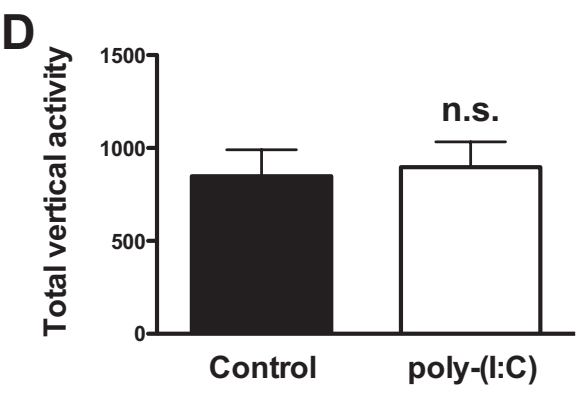

Figure 7. Horizontal activity $(\boldsymbol{A}, \boldsymbol{B})$ and vertical activity $(\boldsymbol{C}, \boldsymbol{D})$ in adult mice born to mothers injected with poly $(\mathrm{l}: \mathrm{C})$ during pregnancy. Both time course $(\boldsymbol{A}, \boldsymbol{C})$ and total counts $(\boldsymbol{B}, \boldsymbol{D})$ of the effects of maternal stress are shown $(n=11-12)$. n.S., Not significant; Student's $t$ test. All data are presented as mean \pm SEM.

gether, these findings suggest that the maternal immune system plays a pivotal role in the schizophrenia-like alterations of $5-\mathrm{HT}_{2 \mathrm{~A}}$ and $\mathrm{mGlu} 2$ receptors induced by adverse life events during pregnancy in the adult offspring.

As demonstrated here (Fig. 5) and reported previously (Asp et al., 2005; Meyer et al., 2009b; Moreno et al., 2011), the schizophrenia-like alterations induced by either maternal variable stress or maternal viral infection during pregnancy were not observed in prepubertal mice. Given that, in humans, the onset of schizophrenia typically occurs during late adolescence or early adulthood, these findings support the validity of using murine models of maternal adverse life events. The symptoms of schizophrenia include "positive" symptoms (e.g., hallucinations and delusions), negative symptoms (e.g., social withdrawal, apathy, and abnormal emotional responses), and cognitive deficits. Psychedelic drugs produce psychotic symptoms and cognitive deficits similar to those observed in schizophrenic patients (Vollenweider et al., 1998; Geyer and Vollenweider, 2008; González-Maeso and Sealfon, 2009). Our investigation was focused on whether maternal variable stress alters the behavioral responses induced by psychedelic drugs, such as DOI and MK801. It is of interest to note that, in schizophrenia patients, cognitive symptoms are usually present, to a lesser degree, before the onset of psychotic symptoms. We show that maternal immune activation during pregnancy leads to cognitive impairments on the T-maze task. Additional work will be directed to assess the neurodevelopmental mechanisms through which maternal immune activation during pregnancy alters cognitive function in the offspring.

The spontaneous activity in the open field represents a behavioral paradigm that mimics the natural conflict in mice between their tendency to explore a novel environment and aversion to heights and open spaces. Recent studies suggest that schizophrenia patients exhibit greater exploratory behavior in an open-field paradigm (Perry et al., 2009). However, locomotor response to novelty has been shown to be higher (Matrisciano et al., 2012), lower (Franklin et al., 2010), and unchanged (Koenig et al., 2005; Van den Hove et al., 2006) in rodent models of prenatal stress. We report here that total distance traveled and rearing (model of behavioral exploration) were unaffected in adult offspring after prenatal stress (Fig. 2) or maternal injection with poly(I:C) (Fig. 7). However, this contrasts with our previous studies showing that mice born to influenza-virus-infected mothers during pregnancy display strong deficits in horizontal and vertical exploratory activity (Moreno et al., 2011). Differences in the severity of the adverse life event paradigm may account for these discrepant data.

In general, clinical studies provide evidence of differences between the genders in schizophrenia (Nopoulos et al., 1997). Males have an earlier age at onset (Lewine et al., 1991), more severe negative symptoms (Castle and Murray, 1991), higher incidence of maternal obstetric complications as a risk factor (Pearlson et al., 1985), and poorer response to antipsychotic treatment (Seeman, 1986). Women have a second peak of incidence during their late 40s to mid-50s (Kenna et al., 2010). Most of the studies in rodents, including ours, compare the risk of schizophrenia-like alterations among the male offspring of mothers that were exposed to adverse life events during pregnancy. However, recent findings suggest that early stress impacts differently on males and females (Koenig et al., 2005; Van den Hove et al., 2006; Franklin et al., 2010). Additional work will be directed to assess the contribution of the gender to the effects of maternal stress during pregnancy on the expression of $5-\mathrm{HT}_{2 \mathrm{~A}}$ and mGlu2 receptors in the adult offspring.

Maternal perturbations do not stop at birth with the cessation of the paradigm of stress but can continue throughout lactation, altering the relationship between pups and dams (de Kloet and Oitzl, 2003; Darnaudéry et al., 2004; Smith et al., 2004). Maternal behavior and adverse early life events can also induce long-lasting epigenetic alterations (McGowan et al., 2009; Gatt et al., 2010). Although a complete analysis of maternal behavior has not been conducted, our findings suggest that the schizophrenia-like behavioral alterations were increased in prenatally stressed mice that were raised by unstressed surrogate mothers. These findings suggest that the neuropsychological changes observed in the adult offspring are a consequence of prenatal environmental insults and not of maternal behavior after pregnancy.

The role of the maternal immune activation during pregnancy is supported by our findings that single injection with poly(I:C) induces a pattern of alteration in expression and behavioral function of the $5-\mathrm{HT}_{2 \mathrm{~A}}$ and the mGlu2 receptors in the adult offspring similar to that observed in mouse models of maternal influenza viral infection (Moreno et al., 2011) and maternal variable stress. The molecular mechanisms by which components of the maternal immune system affected by adverse life events are involved in the schizophrenia-like alterations observed in the adult offspring remain to be investigated but may include, for instance, cytokines and chemokines, such as IL-8 (Brown et al., 2004a), IL-6 (Smith et al., 2007), IL-10 (Meyer et al., 2008), as recent evidence sug- 
A
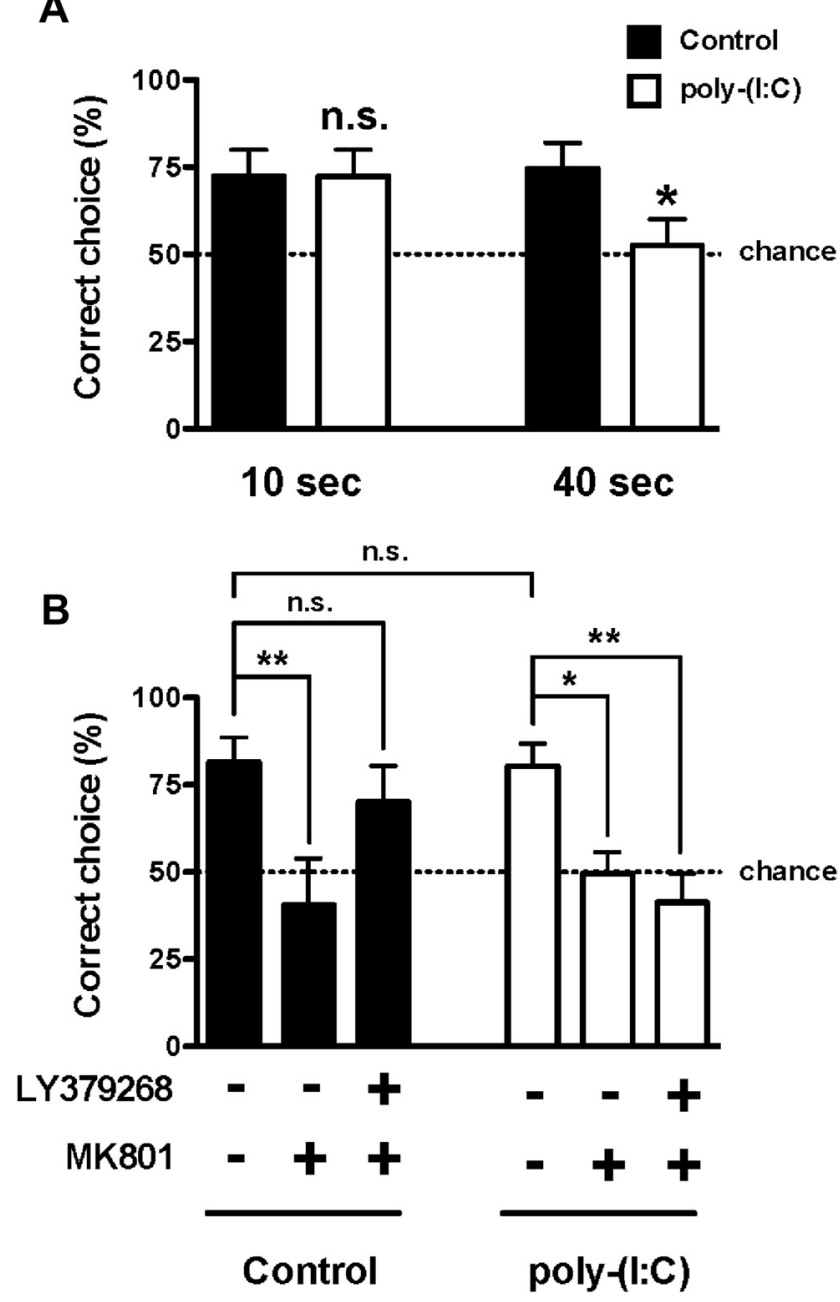

Figure 8. Effect of maternal injection with poly $(\mathrm{l}: \mathrm{C})$ on choice accuracy in the discrete-trial delayed spatial alternation task. $\boldsymbol{A}$, Animals were tested at two delay intervals: 10 and 40 s. Mice born to mothers injected with poly $(\mathrm{l}: \mathrm{C})$ during pregnancy made significantly fewer correct choices after the $40 s$ delay relative to the $10 s$ delay ( $n=11-12$ per group). ${ }^{*} p<0.05$, Student's $t$ test; n.S., not significant. $\boldsymbol{B}$, Maternal injection with poly $(\mathrm{l}: \mathrm{C})$ during pregnancy attenuates the reversal of MK801-impaired delayed alternation memory performance (percentage of correct trials) by LY379268. Mice were administered LY379268 (5 mg/kg) or vehicle, followed by MK801 (0.5 mg/kg; $n=9-12) .{ }^{*} p<0.05,{ }^{* *} p<0.01$, Bonferroni's post hoc test of two-way ANOVA; n.s., not significant. The dashed line indicates chance performance. All data are presented as mean \pm SEM.

gests. Similarly, whether effects of prenatal insults on the adult offspring HPA axis are involved in these schizophrenia-like alterations requires additional investigation (Welberg and Seckl, 2001; Koenig et al., 2002; Keller et al., 2006).

In conclusion, we demonstrate that deleterious environmental factors occurring during pregnancy have profound effects on frontal cortex $5-\mathrm{HT}_{2 \mathrm{~A}}$ and the mGlu2 receptors in the adult offspring and that these alterations are associated with schizophrenia-like behavioral changes. Our results reinforce previous observations in mouse models of maternal influenza viral infection and postmortem human brain of schizophrenic subjects (González-Maeso et al., 2008; Moreno et al., 2011). The impact of early stress is also transmitted across generations (Franklin et al., 2010), and administration of atypical antipsychotics, such as clozapine, prevents the neuropathological alterations induced by maternal immune activation during pregnancy (Piontkewitz et al., 2009, 2011). Our findings further support the hypothesis that activation of the maternal immune system is involved, at least in part, in the pathology of schizophrenia and provide a rodent model that may help in discovering therapeutic targets to prevent the onset of this psychiatric disorder.

\section{References}

Abdolmaleky HM, Yaqubi S, Papageorgis P, Lambert AW, Ozturk S, Sivaraman V, Thiagalingam S (2011) Epigenetic dysregulation of HTR2A in the brain of patients with schizophrenia and bipolar disorder. Schizophr Res 129:183-190. CrossRef Medline

Ashdown H, Dumont Y, Ng M, Poole S, Boksa P, Luheshi GN (2006) The role of cytokines in mediating effects of prenatal infection on the fetus: implications for schizophrenia. Mol Psychiatry 11:47-55. CrossRef Medline

Asp L, Beraki S, Aronsson F, Rosvall L, Ogren SO, Kristensson K, Karlsson H (2005) Gene expression changes in brains of mice exposed to a maternal virus infection. Neuroreport 16:1111-1115. CrossRef Medline

Bradford AM, Savage KM, Jones DN, Kalinichev M (2010) Validation and pharmacological characterisation of MK-801-induced locomotor hyperactivity in BALB/C mice as an assay for detection of novel antipsychotics. Psychopharmacology (Berl) 212:155-170. CrossRef Medline

Brown AS, Cohen P, Harkavy-Friedman J, Babulas V, Malaspina D, Gorman JM, Susser ES (2001) A.E. Bennett Research Award. Prenatal rubella, premorbid abnormalities, and adult schizophrenia. Biol Psychiatry 49: 473-486. CrossRef Medline

Brown AS, Begg MD, Gravenstein S, Schaefer CA, Wyatt RJ, Bresnahan M, Babulas VP, Susser ES (2004a) Serologic evidence of prenatal influenza in the etiology of schizophrenia. Arch Gen Psychiatry 61:774-780. CrossRef Medline

Brown AS, Hooton J, Schaefer CA, Zhang H, Petkova E, Babulas V, Perrin M, Gorman JM, Susser ES (2004b) Elevated maternal interleukin-8 levels and risk of schizophrenia in adult offspring. Am J Psychiatry 161:889895. CrossRef Medline

Brown AS, Schaefer CA, Quesenberry CP Jr, Liu L, Babulas VP, Susser ES (2005) Maternal exposure to toxoplasmosis and risk of schizophrenia in adult offspring. Am J Psychiatry 162:767-773. CrossRef Medline

Cai Z, Pan ZL, Pang Y, Evans OB, Rhodes PG (2000) Cytokine induction in fetal rat brains and brain injury in neonatal rats after maternal lipopolysaccharide administration. Pediatr Res 47:64-72. CrossRef Medline

Canal CE, Olaghere da Silva UB, Gresch PJ, Watt EE, Sanders-Bush E, Airey DC (2010) The serotonin 2C receptor potently modulates the headtwitch response in mice induced by a phenethylamine hallucinogen. Psychopharmacology (Berl) 209:163-174. CrossRef Medline

Cardno AG, Gottesman II (2000) Twin studies of schizophrenia: from bowand-arrow concordances to star wars $\mathrm{Mx}$ and functional genomics. Am J Med Genet 97:12-17. CrossRef Medline

Castle DJ, Murray RM (1991) The neurodevelopmental basis of sex differences in schizophrenia. Psychol Med 21:565-575. CrossRef Medline

Clancy B, Finlay BL, Darlington RB, Anand KJ (2007) Extrapolating brain development from experimental species to humans. Neurotoxicology 28 : 931-937. CrossRef Medline

Darnaudéry M, Dutriez I, Viltart O, Morley-Fletcher S, Maccari S (2004) Stress during gestation induces lasting effects on emotional reactivity of the dam rat. Behav Brain Res 153:211-216. CrossRef Medline

Deacon RM, Rawlins JN (2006) T-maze alternation in the rodent. Nat Protoc 1:7-12. CrossRef Medline

de Kloet ER, Oitzl MS (2003) Who cares for a stressed brain? The mother, the kid or both? Neurobiol Aging 24 [Suppl 1]:S61-S65; discussion S67S68. CrossRef Medline

Egan MF, Straub RE, Goldberg TE, Yakub I, Callicott JH, Hariri AR, Mattay VS, Bertolino A, Hyde TM, Shannon-Weickert C, Akil M, Crook J, Vakkalanka RK, Balkissoon R, Gibbs RA, Kleinman JE, Weinberger DR (2004) Variation in GRM3 affects cognition, prefrontal glutamate, and risk for schizophrenia. Proc Natl Acad Sci U S A 101:12604-12609. CrossRef Medline

Elvevåg B, Goldberg TE (2000) Cognitive impairment in schizophrenia is the core of the disorder. Crit Rev Neurobiol 14:1-21. Medline

Franklin TB, Russig H, Weiss IC, Gräff J, Linder N, Michalon A, Vizi S, Mansuy IM (2010) Epigenetic transmission of the impact of early stress across generations. Biol Psychiatry 68:408-415. CrossRef Medline

Fribourg M, Moreno JL, Holloway T, Provasi D, Baki L, Mahajan R, Park G, Adney SK, Hatcher C, Eltit JM, Ruta JD, Albizu L, Li Z, Umali A, Shim J, 
Fabiato A, Mackerell AD, Jr., Brezina V, Sealfon SC, Filizola M, GonzálezMaeso J, Logothetis DE (2011) Decoding the Signaling of a GPCR Heteromeric Complex Reveals a Unifying Mechanism of Action of Antipsychotic Drugs. Cell 147:1011-1023. CrossRef Medline

García-Bueno B, Caso JR, Leza JC (2008) Stress as a neuroinflammatory condition in brain: damaging and protective mechanisms. Neurosci Biobehav Rev 32:1136-1151. CrossRef Medline

Gatt JM, Nemeroff CB, Schofield PR, Paul RH, Clark CR, Gordon E, Williams LM (2010) Early life stress combined with serotonin 3A receptor and brain-derived neurotrophic factor valine 66 to methionine genotypes impacts emotional brain and arousal correlates of risk for depression. Biol Psychiatry 68:818-824. CrossRef Medline

Geyer MA, Vollenweider FX (2008) Serotonin research: contributions to understanding psychoses. Trends Pharmacol Sci 29:445-453. CrossRef Medline

González-Maeso J, Sealfon SC (2009) Psychedelics and schizophrenia. Trends Neurosci 32:225-232. CrossRef Medline

González-Maeso J, Weisstaub NV, Zhou M, Chan P, Ivic L, Ang R, Lira A, Bradley-Moore M, Ge Y, Zhou Q, Sealfon SC, Gingrich JA (2007) Hallucinogens recruit specific cortical 5-HT(2A) receptor-mediated signaling pathways to affect behavior. Neuron 53:439-452. CrossRef Medline

González-Maeso J, Ang RL, Yuen T, Chan P, Weisstaub NV, López-Gimenez JF, Zhou M, Okawa Y, Callado LF, Milligan G, Gingrich JA, Filizola M, Meana JJ, Sealfon SC (2008) Identification of a serotonin/glutamate receptor complex implicated in psychosis. Nature 452:93-97. CrossRef Medline

Gottesman II, Erlenmeyer-Kimling L (2001) Family and twin strategies as a head start in defining prodromes and endophenotypes for hypothetical early-interventions in schizophrenia. Schizophr Res 51:93-102. CrossRef Medline

Ibrahim HM, Tamminga CA (2011) Schizophrenia: treatment targets beyond monoamine systems. Annu Rev Pharmacol Toxicol 51:189-209. CrossRef Medline

International Schizophrenia Consortium (2008) Rare chromosomal deletions and duplications increase risk of schizophrenia. Nature 455:237241. CrossRef Medline

Keller PA, McCluskey A, Morgan J, O'Connor SM (2006) The role of the HPA axis in psychiatric disorders and CRF antagonists as potential treatments. Arch Pharm (Weinheim) 339:346-355. CrossRef Medline

Kenna HA, Ghezel T, Rasgon NL (2010) Epidemiology of mental disorders in older women. In: A public health prespective of women's mental health (Levin BL, Becker MA, eds), pp 65-80. New York: Springer Science.

Khashan AS, Abel KM, McNamee R, Pedersen MG, Webb RT, Baker PN, Kenny LC, Mortensen PB (2008) Higher risk of offspring schizophrenia following antenatal maternal exposure to severe adverse life events. Arch Gen Psychiatry 65:146-152. CrossRef Medline

Koenig JI, Kirkpatrick B, Lee P (2002) Glucocorticoid hormones and early brain development in schizophrenia. Neuropsychopharmacology 27: 309-318. CrossRef Medline

Koenig JI, Elmer GI, Shepard PD, Lee PR, Mayo C, Joy B, Hercher E, Brady DL (2005) Prenatal exposure to a repeated variable stress paradigm elicits behavioral and neuroendocrinological changes in the adult offspring: potential relevance to schizophrenia. Behav Brain Res 156:251-261. CrossRef Medline

Kurita M, Holloway T, García-Bea A, Kozlenkov A, Friedman AK, Moreno JL, Heshmati M, Golden SA, Kennedy PJ, Takahashi N, Dietz DM, Mocci G, Gabilondo AM, Hanks J, Umali A, Callado LF, Gallitano AL, Neve RL, Shen L, Buxbaum JD, Han MH, Nestler EJ, Meana JJ, Russo SJ, GonzálezMaeso J (2012) HDAC2 regulates atypical antipsychotic responses through the modulation of mGlu2 promoter activity. Nat Neurosci 15: 1245-1254. CrossRef Medline

Lett TA, Wallace TJ, Chowdhury NI, Tiwari AK, Kennedy JL, Müller DJ (2012) Pharmacogenetics of antipsychotic-induced weight gain: review and clinical implications. Mol Psychiatry 17:242-266. CrossRef Medline

Lewine R, Flashman L, Gulley L, Beardsley S, Wasserman A, Lucas M, Risch SC (1991) Sexual dimorphism in corpus callosum and schizophrenia. Schizophr Res 4:63-64. CrossRef Medline

Lieberman JA, Bymaster FP, Meltzer HY, Deutch AY, Duncan GE, Marx CE, Aprille JR, Dwyer DS, Li XM, Mahadik SP, Duman RS, Porter JH, Modica-Napolitano JS, Newton SS, Csernansky JG (2008) Antipsychotic drugs: comparison in animal models of efficacy, neurotransmitter regulation, and neuroprotection. Pharmacol Rev 60:358-403. CrossRef Medline

Liu W, Downing AC, Munsie LM, Chen P, Reed MR, Ruble CL, Landschulz KT, Kinon BJ, Nisenbaum LK (2012) Pharmacogenetic analysis of the mGlu2/3 agonist LY2140023 monohydrate in the treatment of schizophrenia. Pharmacogenomics J 12:246-254. CrossRef Medline

Malaspina D, Corcoran C, Kleinhaus KR, Perrin MC, Fennig S, Nahon D, Friedlander Y, Harlap S (2008) Acute maternal stress in pregnancy and schizophrenia in offspring: a cohort prospective study. BMC Psychiatry 8:71. CrossRef Medline

Matrisciano F, Dong E, Gavin DP, Nicoletti F, Guidotti A (2011) Activation of group II metabotropic glutamate receptors promotes DNA demethylation in the mouse brain. Mol Pharmacol 80:174-182. CrossRef Medline

Matrisciano F, Tueting P, Maccari S, Nicoletti F, Guidotti A (2012) Pharmacological activation of group-II metabotropic glutamate receptors corrects a schizophrenia-like phenotype induced by prenatal stress in mice. Neuropsychopharmacology 37:929-938. CrossRef Medline

McGowan PO, Sasaki A, D’Alessio AC, Dymov S, Labont é B, Szyf M, Turecki G, Meaney MJ (2009) Epigenetic regulation of the glucocorticoid receptor in human brain associates with childhood abuse. Nat Neurosci 12: 342-348. CrossRef Medline

Menninger KA (1919) Psychoses associated with influenza. J. Am Med Assoc 72:235-241. CrossRef

Meyer U, Nyffeler M, Engler A, Urwyler A, Schedlowski M, Knuesel I, Yee BK, Feldon J (2006) The time of prenatal immune challenge determines the specificity of inflammation-mediated brain and behavioral pathology. J Neurosci 26:4752-4762. CrossRef Medline

Meyer U, Murray PJ, Urwyler A, Yee BK, Schedlowski M, Feldon J (2008) Adult behavioral and pharmacological dysfunctions following disruption of the fetal brain balance between pro-inflammatory and IL-10-mediated anti-inflammatory signaling. Mol Psychiatry 13:208-221. CrossRef Medline

Meyer U, Feldon J, Yee BK (2009a) A review of the fetal brain cytokine imbalance hypothesis of schizophrenia. Schizophr Bull 35:959-972. CrossRef Medline

Meyer U, Feldon J, Fatemi SH (2009b) In-vivo rodent models for the experimental investigation of prenatal immune activation effects in neurodevelopmental brain disorders. Neurosci Biobehav Rev 33:1061-1079. CrossRef Medline

Moreno JL, Sealfon SC, González-Maeso J (2009) Group II metabotropic glutamate receptors and schizophrenia. Cell Mol Life Sci 66:3777-3785. CrossRef Medline

Moreno JL, Kurita M, Holloway T, López J, Cadagan R, Martínez-Sobrido L, García-Sastre A, González-Maeso J (2011) Maternal influenza viral infection causes schizophrenia-like alterations of $5-\mathrm{HT}_{2 \mathrm{~A}}$ and $\mathrm{mGlu} 2$ receptors in the adult offspring. J Neurosci 31:1863-1872. CrossRef Medline

Morgan CP, Bale TL (2011) Early prenatal stress epigenetically programs dysmasculinization in second-generation offspring via the paternal lineage. J Neurosci 31:11748-11755. CrossRef Medline

Murgatroyd C, Patchev AV, Wu Y, Micale V, Bockmühl Y, Fischer D, Holsboer F, Wotjak CT, Almeida OF, Spengler D (2009) Dynamic DNA methylation programs persistent adverse effects of early-life stress. Nat Neurosci 12:1559-1566. CrossRef Medline

Nestler EJ, Hyman SE (2010) Animal models of neuropsychiatric disorders. Nat Neurosci 13:1161-1169. CrossRef Medline

Nopoulos P, Flaum M, Andreasen NC (1997) Sex differences in brain morphology in schizophrenia. Am J Psychiatry 154:1648-1654. Medline

Pearlson GD, Garbacz DJ, Moberg PJ, Ahn HS, DePaulo JR (1985) Symptomatic, familial, perinatal, and social correlates of computerized axial tomography (CAT) changes in schizophrenics and bipolars. J Nerv Ment Dis 173:42-50. CrossRef Medline

Perry W, Minassian A, Paulus MP, Young JW, Kincaid MJ, Ferguson EJ, Henry BL, Zhuang X, Masten VL, Sharp RF, Geyer MA (2009) A reverse-translational study of dysfunctional exploration in psychiatric disorders: from mice to men. Arch Gen Psychiatry 66:1072-1080. CrossRef Medline

Piontkewitz Y, Assaf Y, Weiner I (2009) Clozapine administration in adolescence prevents postpubertal emergence of brain structural pathology in an animal model of schizophrenia. Biol Psychiatry 66:1038-1046. CrossRef Medline

Piontkewitz Y, Arad M, Weiner I (2011) Risperidone administered during asymptomatic period of adolescence prevents the emergence of brain 
structural pathology and behavioral abnormalities in an animal model of schizophrenia. Schizophr Bull 37:1257-1269. CrossRef Medline

Purcell SM, Wray NR, Stone JL, Visscher PM, O’Donovan MC, Sullivan PF, Sklar P (2009) Common polygenic variation contributes to risk of schizophrenia and bipolar disorder. Nature 460:748-752. CrossRef Medline

Quednow BB, Kühn KU, Mössner R, Schwab SG, Schuhmacher A, Maier W, Wagner M (2008) Sensorimotor gating of schizophrenia patients is influenced by 5-HT2A receptor polymorphisms. Biol Psychiatry 64:434437. CrossRef Medline

Schweitzer C, Kratzeisen C, Adam G, Lundstrom K, Malherbe P, Ohresser S, Stadler H, Wichmann J, Woltering T, Mutel V (2000) Characterization of [(3)H]-LY354740 binding to rat mGlu2 and mGlu3 receptors expressed in CHO cells using semliki forest virus vectors. Neuropharmacology 39:1700-1706. CrossRef Medline

Seeman MV (1986) Current outcome in schizophrenia: women vs men. Acta Psychiatr Scand 73:609-617. CrossRef Medline

Seo YJ, Kwon MS, Shim EJ, Park SH, Choi OS, Suh HW (2006) Changes in pain behavior induced by formalin, substance $\mathrm{P}$, glutamate and proinflammatory cytokines in immobilization-induced stress mouse model. Brain Res Bull 71:279-286. CrossRef Medline

Smith JW, Seckl JR, Evans AT, Costall B, Smythe JW (2004) Gestational stress induces post-partum depression-like behaviour and alters maternal care in rats. Psychoneuroendocrinology 29:227-244. CrossRef Medline

Smith SE, Li J, Garbett K, Mirnics K, Patterson PH (2007) Maternal immune activation alters fetal brain development through interleukin-6. J Neurosci 27:10695-10702. CrossRef Medline

Stefansson H, Rujescu D, Cichon S, Pietiläinen OP, Ingason A, Steinberg S, Fossdal R, Sigurdsson E, Sigmundsson T, Buizer-Voskamp JE, Hansen T, Jakobsen KD, Muglia P, Francks C, Matthews PM, Gylfason A, Halldorsson BV, Gudbjartsson D, Thorgeirsson TE, Sigurdsson A, et al. (2008) Large recurrent microdeletions associated with schizophrenia. Nature 455:232-236. CrossRef Medline

Stefansson H, Ophoff RA, Steinberg S, Andreassen OA, Cichon S, Rujescu D, Werge T, Pietiläinen OP, Mors O, Mortensen PB, Sigurdsson E, Gustafs- son $\mathrm{O}$, Nyegaard $\mathrm{M}$, Tuulio-Henriksson A, Ingason A, Hansen T, Suvisaari J, Lonnqvist J, Paunio T, Børglum AD, et al. (2009) Common variants conferring risk of schizophrenia. Nature 460:744-747. Medline

Steptoe A, Willemsen G, Owen N, Flower L, Mohamed-Ali V (2001) Acute mental stress elicits delayed increases in circulating inflammatory cytokine levels. Clin Sci (Lond) 101:185-192. CrossRef Medline

Susser E, St Clair D, He L (2008) Latent effects of prenatal malnutrition on adult health: the example of schizophrenia. Ann N Y Acad Sci 1136:185-192. CrossRef Medline

Van den Hove DL, Lauder JM, Scheepens A, Prickaerts J, Blanco CE, Steinbusch HW (2006) Prenatal stress in the rat alters 5-HT1A receptor binding in the ventral hippocampus. Brain Res 1090:29-34. CrossRef Medline

van Os J, Selten JP (1998) Prenatal exposure to maternal stress and subsequent schizophrenia. The May 1940 invasion of The Netherlands. Br J Psychiatry 172:324-326. CrossRef Medline

Vanbesien-Mailliot CC, Wolowczuk I, Mairesse J, Viltart O, Delacre M, Khalife J, Chartier-Harlin MC, Maccari S (2007) Prenatal stress has proinflammatory consequences on the immune system in adult rats. Psychoneuroendocrinology 32:114-124. CrossRef Medline

Vollenweider FX, Vollenweider-Scherpenhuyzen MF, Bäbler A, Vogel H, Hell D (1998) Psilocybin induces schizophrenia-like psychosis in humans via a serotonin-2 agonist action. Neuroreport 9:3897-3902. CrossRef Medline

Walsh T, McClellan JM, McCarthy SE, Addington AM, Pierce SB, Cooper GM, Nord AS, Kusenda M, Malhotra D, Bhandari A, Stray SM, Rippey CF, Roccanova P, Makarov V, Lakshmi B, Findling RL, Sikich L, Stromberg T, Merriman B, Gogtay N, et al (2008) Rare structural variants disrupt multiple genes in neurodevelopmental pathways in schizophrenia. Science 320:539-543. CrossRef Medline

Welberg LA, Seckl JR (2001) Prenatal stress, glucocorticoids and the programming of the brain. J Neuroendocrinol 13:113-128. CrossRef Medline

Woolley ML, Pemberton DJ, Bate S, Corti C, Jones DN (2008) The mGlu2 but not the mGlu3 receptor mediates the actions of the mGluR2/3 agonist, LY379268, in mouse models predictive of antipsychotic activity. Psychopharmacology (Berl) 196:431-440. CrossRef Medline 